\title{
EXPLORING THE SITE SELECTION DECISIONS OF INCENTIVE TRAVEL PLANNERS
}

\author{
JUDITH MAIR,* XIN (CATHY) JIN,† AND JOANNE JUNG-EUN YOO \\ *UQ Business School, University of Queensland, St Lucia, QLD, Australia \\ †Department of Tourism, Sports and Hotel Management, Griffith Business School, \\ Griffith University, Southport, QLD, Australia \\ ¥Hotel, Restaurant and Institutional Management, Alfred Lerner College of Business and Economics, \\ University of Delaware, Newark, DE, USA
}

\begin{abstract}
This article examines how incentive travel is conceptualized, planned, and organized in three major markets-Australia, China, and the US. The findings suggest that planners across the three markets share similar perceptions on what characterizes incentive trips but differ slightly in the planning and operational phase pertinent to varying customer characteristics and requirements. This exploratory study provides a basis for future research in the area of incentive travel and useful information for incentive travel planners.
\end{abstract}

Key words: Incentive travel; Site selection; Business events; Planners

Introduction

Business events are of enormous importance to the economies of many destinations worldwide (Jago, Mair, Deery, \& Bergin-Seers, 2008). As a term, "business events" is generally understood to include meetings, incentives, conventions, and exhibitions. While this is a complex and diverse sector, it is one that now helps underpin tourist visitation for many destinations. Such destinations have made substantial investments to provide the meeting facilities and hotel accommodation needed for business events. The global economic importance of this sector is difficult to define with any authority, as global figures are not available; however, some figures for individual nations can be ascertained. The American meetings and events industry directly and indirectly supports 6.3 million jobs and generates almost $\$ 1$ trillion a year in direct, indirect, and induced spending (Sanders, 2011). In the UK, more than 1.3 million meetings were held in 2011, attended by 116 million people who spent almost $£ 40$ billion (Hall \& Ledger, 2013). Even in smaller economies, such as Australia, the business events sector is widely accepted as being of vital importance and resulted in business event visitor 
spend of AU\$8,433 million (Deery, Jago, Fredline, \& Dwyer, 2005).

One aspect of business events that remains notoriously underresearched is incentives (Mair, 2012). Incentive travel is defined as a global management tool that uses an exceptional travel experience to motivate and/or recognize participants for increased levels of performance at work (Society of Incentive Travel Executives [SITE], 2013). The incentive travel acts as a reward for recipients who may spend significant time away from workrelated activities during their trip. In the US, there were approximately 66,000 incentive meetings in 2011 (Sanders, 2011). Australia is a sought-after destination for many incentive travelers, and as such there has been somewhat more research in this context. Tourism Australia (2008) indicated that most international incentive visitors were from China (34\%), New Zealand (12\%), and Japan (10\%). The global value of incentive travel to the world economy is difficult to judge, but international incentive visitors spent \$210 million while in Australia and domestic incentive visitors spent $\$ 175$ million during the first quarter of 2008 (Tourism Australia, 2008). The Asian outbound market is of particular importance to the Australian incentive industry. In 2010, Amway International brought 7,200 Chinese incentive travelers to Melbourne for a leadership seminar. Their estimated expenditure was \$18.6 million, representing a significant boost to the Australian economy (Melbourne Convention and Visitor Bureau [MCVB], 2010). In March 2015, Tupperware Indonesia sent an incentive group of 4,000 of its high performance sales managers, team leaders, and distributors to Melbourne for a 4-day incentive program, the single largest incentive group from the country, delivering an estimated \$19 million economic contribution to Victoria (Incentive Travel and Corporate Meetings [ITCM], 2015). However, little is known about the cultural differences in incentive programs from one country to the next. Further, it appears that scant research has considered how cross-cultural differences in incentive travel are perceived.

Despite a limited amount of information on expenditure and the number of incentive programs, there remain numerous gaps in our understanding of this sector of business events, including how incentive travel organizers select their travel destination, and how this process may differ between source markets. Indeed, very few studies have examined the site selection process of incentive planners (an exception is Del Chiappa, 2012). However, there is an established literature on the site selection process of convention organizers (e.g., Crouch, 2011; Crouch \& Louviere, 2004), and arguably there may be similarities between the destination characteristics sought by convention planners and those sought by incentive travel organizers, because both are organizing business events for professionals. This exploratory article aims to examine these site selection factors in the incentive travel context and identify any similarities and differences in how incentive travel is conceptualized, planned, and organized in three different countries-Australia, China, and the US. The article will begin with a review of the existing literature on incentive travel, and will move on to engage with the convention planning and site selection literature. The article will then discuss and justify the methods chosen for this study, and will identify the findings that have emerged. The article will conclude with a discussion of how these findings relate to our existing knowledge of incentive planning, and will identify avenues for future research in this area.

\section{Literature Review}

\section{Incentive Travel}

The incentive market has not been studied in great depth as an individual market segment. In a review of business events literature from 2000 to 2009 by Mair (2012), only one tourism journal published an article on incentive travel-Xiang and Formica (2007). This may be in part attributable to the fact that it is hard to differentiate between those traveling on business trips and those traveling on incentive trips, because both are paid for by businesses and a proportion of incentive trips include an element of business, such as a meeting or tour of company offices. In addition, there are commercialin-confidence reasons for not publicizing details or information about incentive trips provided by large corporations. Research by Sheldon (1995) highlighted that travel was seen as a popular reward or incentive among America's Fortune 100 companies, and that travel incentives were most likely to 
be used by companies in the service sector. Shinew and Backman (1995) identified the "trophy value" of travel incentives, and proposed that incentive travel allows long-lasting positive reinforcement for those who are rewarded in this way. However, their research also suggested that while travel incentives were the most attractive for employees, cash incentives lead to greater increases in employee productivity. The research by Xiang and Formica (2007) used cognitive mapping to understand and interpret how incentive travel managers view their business environment, concluding that the incentive travel market is fast paced, and global structural and environmental changes present challenges to incentive planners.

Factors influencing the choice of destination for incentive travel are thought to include budget and cost, uniqueness of the destination, availability of suitable facilities, climate and sightseeing, and cultural attractions (Mair, 2005); however, this has not yet been demonstrated in empirical research.

\section{Convention Site Selection}

According to Crouch and Ritchie (1997) "the choice of destination can make or break the convention” (p. 52). Montgomery and Strick (1995) feel that "regardless of the type of meeting, convention or exposition, the site is a critical factor in the success and failure of the event” (p. 109).

Fortin and Ritchie (1977) were among the first researchers to consider the process undertaken by meeting planners when deciding on which location to choose for their annual meeting or convention. Their research suggested that there were groups of characteristics or services that were of significance to convention planners. They identified these as functional services (e.g., hotel rooms, air access and ground transport options); local support; touristic appeal (e.g., climate, scenery, and local attractions); personal and professional benefits (e.g., networking opportunities); and finally what they termed as diversionary value-recreational and other activities for spouses and families.

In addition, Bonn, Brand, and Ohlin (1994) suggested that the possibility of negotiating budgets and the quality of food and services were of particular importance to association meeting planners, while Jun and McCleary (1999) pointed to the significance of the attractiveness of the site, cost and value, the distance attendees would have to travel to reach the site, and the social elements available on site.

Go and Zhang (1997) classified convention site selection criteria into two main categories-the convention destination itself, and its meeting facilities. Some factors are clearly related to the destination (e.g., extra-conference opportunities and site environment) and to meeting facilities. However, some of these factors are not so easy to allocate to one or the other-for example, the risks and profitability aspects may relate to both the destination and the specific meeting venue. Opperman (1996) isolates five main factors in the association meeting planners' decision making process, namely "service," "cost," "image," "location," and "facilities," and draws the conclusion that although "image" was only one among five important factors, "many of the other variables usually contribute to the overall image of a destination as a conference city” (Oppermann, 1996, p. 16). This would suggest that "image" is by far the most important of these factors.

Expanding on this research, seminal work in this area was undertaken by Crouch and Ritchie (1997) and Crouch and Louviere (2004). Many of their findings are similar to those of Fortin and Ritchie (1977), such as local support, extra-conference opportunities and meeting facilities, while others appeared to be new-information on how well the site has performed in the past as a convention destination, for example. Crouch and Louviere (2004) also identified other criteria such as the perceived risks of travel to the destination, as well as the likelihood of hosting a profitable conference in that destination. The nine factors identified by Crouch and Ritchie (1997) are shown in Table 1.

Additional research has also been carried out to try to further characterize the site selection decision. In an attempt to move from simply describing the factors of significance to convention organizers, Crouch and Louviere (2004) used choice modeling to assess the relative importance of these factors in the site selection decision. The top five most important site selection criteria identified by Crouch and Louviere (2004) were the cost of the venue; the quality of the food; the suitability of the plenary room; the availability of on-site accommodation; and the proximity of the site to convention participants. Their findings suggest that meeting and 
Table 1

Convention Site Selection Factors

\begin{tabular}{ll}
\hline Factor & \multicolumn{1}{c}{ Components } \\
\hline Accessibility & Cost; travel time; convenience of travel connections; barriers such as customs and visas \\
Local support & Assistance from a local chapter; support from the CVB; subsidies or subventions \\
Extra-conference opportunities & Entertainment; shopping; sightseeing; recreation; and professional opportunities \\
Accommodation facilities & Capacity; cost; service; security; availability \\
Meeting facilities & Capacity; layout; cost; ambience; service; security; availability \\
Information & Has the site performed well in the past; marketing \\
Site environment & Climate; setting; infrastructure; hospitality \\
Other criteria & e.g., risk; profitability \\
\hline
\end{tabular}

Source: Crouch and Ritchie (1997).

accommodation facilities (particularly their location and cost) and the site environment were the main factors in choosing a convention site. Further, the attractiveness of the site environment was closely related to the proximity of the site to the potential delegates, suggesting that destinations with integrated convention and accommodation facilities are likely to be favored by convention organizers. Another important consideration uncovered by this research was the finding that the degree to which convention attendees could be accommodated on site, as opposed to off site at a distance from the convention venue, made a location more attractive to organizers (Crouch \& Louviere, 2004).

Chen's (2006) work provided further evidence for many of these criteria, but also suggested that destination image was a particularly important consideration in the site selection decision. Research appears to demonstrate that by holding conferences and conventions in destinations that are perceived to be attractive (i.e., have a positive destination image) organizers will be able to maximize attendance (Grant, 1994; M. J. Lee \& Back, 2005, 2007; Opperman, 1995). Chacko and Fenich (2000) also note that the selection of a destination can make or break a conference. Convention destination image (CDI) has been primarily researched from the supply side (meeting planners, convention organizers, and site selectors), although clearly the destination image of a convention site will also influence attendance by delegates (Mair, 2014; Yoo \& Chon, 2008; Yoo \& Zhao, 2010).

There appears to be acceptance that the key factors identified by Fortin and Ritchie (1977), Crouch and Ritchie (1997), Crouch and Louviere (2004), and Chen (2006) are those that are generally taken into account by those choosing a convention destination. Since then, more recent research has examined particular facets of the site selection decision in more detail. Di Pietro, Breiter, Rompf, and Godlewska (2008) highlighted the importance of value for money and the overall cost in site selection, and it may be assumed, given the various economic shocks and crises since then, that these factors will become increasingly important. Budget was also found to be an important part of site selection decision making by Comas and Moscardo (2005). Examining an aspect that had previously been overlooked, S. Lee, Park, and Khan (2012) considered the importance of a range of IT-related factors in the site selection decision. They identified the availability of high speed internet; wireless connectivity; the availability of on-site ICT support; and the availability of an e-mail station for delegates as all being aspects of the site selection decision, most of which appear to fit under the "meeting facilities" factor previously identified (Crouch \& Ritchie, 1997). Additionally, safety and security have been identified as playing an important role for meeting planners when selecting a venue. While such issues have always been important, it is likely that the significance placed on these issues will continue to increase as time goes on, and crises and disasters continue to affect meetings and conventions (Hilliard \& Baloglu, 2008). Finally, there has been a small amount of work on the sustainability and environmental credentials of venues and destinations in relation to site selection. For example, Draper, Dawson, and Casey (2011) identified three areas of sustainable practices that 
are becoming more important to meeting planners when selecting a convention site-energy efficiency, recycling, and venue sustainability policies. However, this is still an emerging area.

Despite our substantial knowledge of the convention site selection process, very little research has considered how those planning different types of meetings choose their destinations. Bonn et al. (1994) consider both association and corporate meeting planners, breaking down the association market into heavy half (four or more meetings per year) and light half (less than four meetings per year) association meeting planners and looking at the differences that arise when planning a corporate conference. Their general conclusions are that "differences exist between corporate and association meeting planners with respect to (1) the attributes most valued, (2) the destinations which they felt best provided those attributes, and (3) the number of meetings planned each year" (Bonn et al., 1994, p. 81).

In one of the few studies to consider the site selection process of incentive planners, Del Chiappa (2012) examined Italian meeting planners to ascertain whether there were differences in how various convention site attributes were assessed between those planning different types of meetings (including conventions, meetings, and incentives). Del Chiappa (2012) found that while many of the attributes measured were of similar importance to all meeting planners (affordability, quality and efficiency of industry personnel, local convention bureau assistance, physical settings, safety and security, and local transport costs and travel times), there were some significant differences. Incentive planners did not rate destination accessibility as being as important as for other meetings planners, perhaps because as Del Chiappa (2012, p. 164) suggests, a certain degree of "destination inaccessibility" could be desirable to set the incentive location apart as being unique and exclusive. Further, destination brand, expected weather, entertainment, and destination novelty were all ranked as being more important to incentive planners than to other types of meeting planners. Given the exploratory nature of this research, Del Chiappa (2012) concludes by suggesting that further research in other countries and context would be valuable. The findings of this research suggest that there are considerable similarities and overlaps between the site selection criteria of incentive planners and those planning conventions and other types of events, thus providing some empirical evidence to underpin the use of existing convention site selection decisionmaking criteria in this research. This article therefore addresses the following research questions-do the site selection criteria identified in the convention literature apply in the incentive travel destination selection context; and do these criteria differ in different countries?

\section{Method}

This article reports on exploratory qualitative research, using in-depth interviews with incentive travel organizers. In-depth interviews are suitable when the researcher is seeking to explore new topics or knowledge areas (Buchanan \& Bryman, 2009). Twelve in-depth interviews (between 30 and $60 \mathrm{~min}$ ) were carried out with incentive travel organizers, of which four were located in Australia, four were located in China, and four were located in the US. The recruitment of interviewees involved a referral system through researchers' personal contacts and incentive organizers' recommendations. Initially, a list of qualified tour operators/ specialists authorized by national tourism bureaus (e.g., China National Tourism Administration, Tourism Australia) was consulted as a sample frame. Potential interviewees were invited by e-mails and internet calls. Representativeness of the interviewees was attempted, to a certain degree, by giving considerations to geographical location and organizational structure: 1) interviewees from different geographical regions-for example, the four Chinese operators were located in Beijing, Guangzhou, Wuhan, and Hong Kong, respectively, covering four key markets within China; 2) interviewees from leading companies in the incentive sector but of different ownership and management structures-for example, in the Chinese case, the tour companies in Beijing and Guangzhou were mainly state-owned enterprises while the companies in Wuhan and Hong Kong were shareholderbased private companies; in Australia and the US interviewees represented a range of different management structures, from employees of large organizations to owner/manager of a small business. Further, all interviewees were senior managers 
in their respective companies. The Chinese interviews were carried out by one of the researchers fluent in Mandarin Chinese. The remaining interviews were carried out in English. Interviewees were asked to give some demographic background on their incentive business, as well as about their views on how "incentive" and "incentive travel" are defined. They were also asked to give information on how their incentive programs were structured and how they built up relationships both with their incentive clients and with local suppliers of their incentive trips, as relationships (e.g., power of clients and suppliers) might influence site selection decision making (Clark, Evans, \& Knutson, 1998). Finally, they were asked in open-ended questions about their views on site selection, with prompts regarding the eight site selection factors identified by Crouch and Ritchie (1997) where necessary. The interviews were recorded with permission, transcribed, and analyzed using open coding. Open coding involves the researcher breaking down the data into its parts and looking for similarities and differences (Strauss \& Corbin, 1990). All data were coded according to themes derived both from the literature [mainly using the elements of the Crouch and Ritchie (1997) study] and from the emergent data. Despite the small sample size (a total of 12 interviews), there was a reasonable level of congruency in the information obtained.

\section{Findings}

\section{Characterizing Incentive Planners and Incentive Trips}

Initially, interviewees were asked about the size of their business, as well as how many incentives trips they plan each year. Interviewees represented companies organizing a range of incentives, from 2 per year to 20 per year, and range of group sizes, from 15-20 all the way up to 250-300. One Chinese interviewee had been involved in organizing an incentive trip for 4,000 people, but most group sizes were much smaller.

There were some clear similarities between the Chinese and Australian planners, with both noting the importance of the reward aspect of incentive travel. It was also pointed out that incentive travel may be in place before targets are met, in order to act as motivation for employees, or may only be announced to reward those employees who had already met their targets. The American planners also noted that as well as motivating and rewarding the employees who are selected to travel on the incentive trip, it was seen as an important recognition of their work, and perhaps by implication, their worth to the company.

In terms of what incentive trips are composed of, planners noted that incentive travel had an important leisure component. For all nationalities, the percentage of leisure time involved in an incentive trip was fairly high - in China incentives were suggested to be around $80 \%$ leisure and $20 \%$ business. Australian planners noted that the incentive travel they planned tended to be at least $70 \%$ leisure time. In fact, the Australian planners suggested that this proportion of leisure would be higher, but that Australian tax laws required business-related aspects to be part of an incentive trip, such as a half day meeting, or site inspection (the Australian tax system requires a certain percentage of business activity on a business trip and if the criteria is not met, then there are substantial taxes to be paid). Questions of tax implications were not seen as being important for the Chinese planners. For the American planners, the general downturn of the economy has led to an increased number of leisure plus business incentives, with the business component helping to justify the expense of an incentive trip.

Both the Chinese and the American planners mentioned the importance of team-building activities during an incentive trip. Chinese incentive travel planners usually plan an interactive program, with a range of activities for all participants. To enhance company culture and collegiality, physically exciting and emotionally uplifting group activities are frequently incorporated in the itinerary as well. One of the characteristics of incentive travel programs organized by Chinese planners is the physically stimulating nature of the activities, with a range of group activities organized, often of a competitive nature. For the US market, there has been an increase in demand for educational activities as part of incentive trips; however, planners noted that "this is still a small proportion. The majority of it, every day, you would have leisure activities.” The Australian planners, on the other hand, suggested that the team-based activities took place during the business 
element of the trip such as during a meeting or site inspection visit. The rest of the time there is ample space in the incentive travel program for participants to relax and "do their own thing."

All meeting planners stated that they organized all elements of incentive programs, including RFPs (Requests for Proposals) and bids, flights, accommodation, transfers, entertainment, design of marketing collateral, contracting, site inspections, budgeting, and invoicing. The key differences noted between the Chinese planners and the Australian and the America planners was that in China, usually one department of a large travel company is named as "meeting and incentive department" and is dedicated to work on the group business travel sector. They work together with other departments in the planning and operation of the trips. There are very few small operators in the sector. However, in both Australia and the US, there are many small operators, not many of whom are associated with large travel companies. The typical Australian incentive planner, for example, is a small to medium enterprise, organizing fewer than 10 incentive trips per year.

Incentive planners often work with other suppliers of travel and tourism products and services, and a point that was highlighted as being very important was networking and relationship building. For all the planners interviewed, the strength of their relationships with suppliers (particularly destination management companies, or other ground-handling agents) was a key factor in organizing incentive trips. As one planner put it "this career is all about relationships. I've got friends all over the world. You definitely need to reply on your suppliers because your suppliers help you look good.” In addition, incentive planners need to develop good relationships with their clients. Chinese planners noted that although they have some loyal clients, this is becoming less usual, and the business is becoming more competitive. From the moment that an incentive planner is awarded a contract to arrange an incentive trip, they will work with their clients to make sure that the final trip meets all their needs, and comes in on budget. Incentive planners also get involved in liaising and communicating directly with the employees who will be traveling on the incentive trip, as well as with the design of marketing collateral to get everyone excited about the trip-“Anticipation of the trip is a big component of making the trip successful." While this was not a key focus of this research, nonetheless, networking and relationships with suppliers and with the incentive participants themselves are important success factors for incentive travel.

\section{Site Selection}

Figure 1 demonstrates the site selection factors that have been identified as part of this research as being of particular importance in the incentive travel context. Many of the site selection factors that are important to convention planners were also found to be of significance to incentive planners. However, other factors (those highlighted in the diagram) appeared to be factors not previously identified in the convention site selection literature. Each factor is discussed in turn in this section.

In this study, the key factors were accessibility of the destination, availability of accommodation, and destination image. The factors that were seen to be less important for incentive planners included meeting facilities and the site environment. Additional important factors that arose, those are not traditionally considered to be site selection factors, were novelty of the destination, perceived risk, and currency/exchange rates. The main difference found between the nationalities of interviewees related to "extra-conference opportunities," which were considered to be nice but not essential, or particularly high on the agenda for the Australian and the American planners, but were seen as very important for the Chinese planners.

Accessibility of the Destination. Accessibility was identified as a top priority for most of the planners interviewed, with destinations that can be reached by direct flights, and destinations that are easy to get to being favored by incentive planners and their clients. Chinese planners also stressed accessibility, although in China, it is often the case that participants come from different cities or regions, and therefore they need to assemble in a gateway city in China before they fly out to an international destination. Thus, convenience in getting to their final destination is of particular significance. It was also emphasized that it is not enough for a destination to have good air 


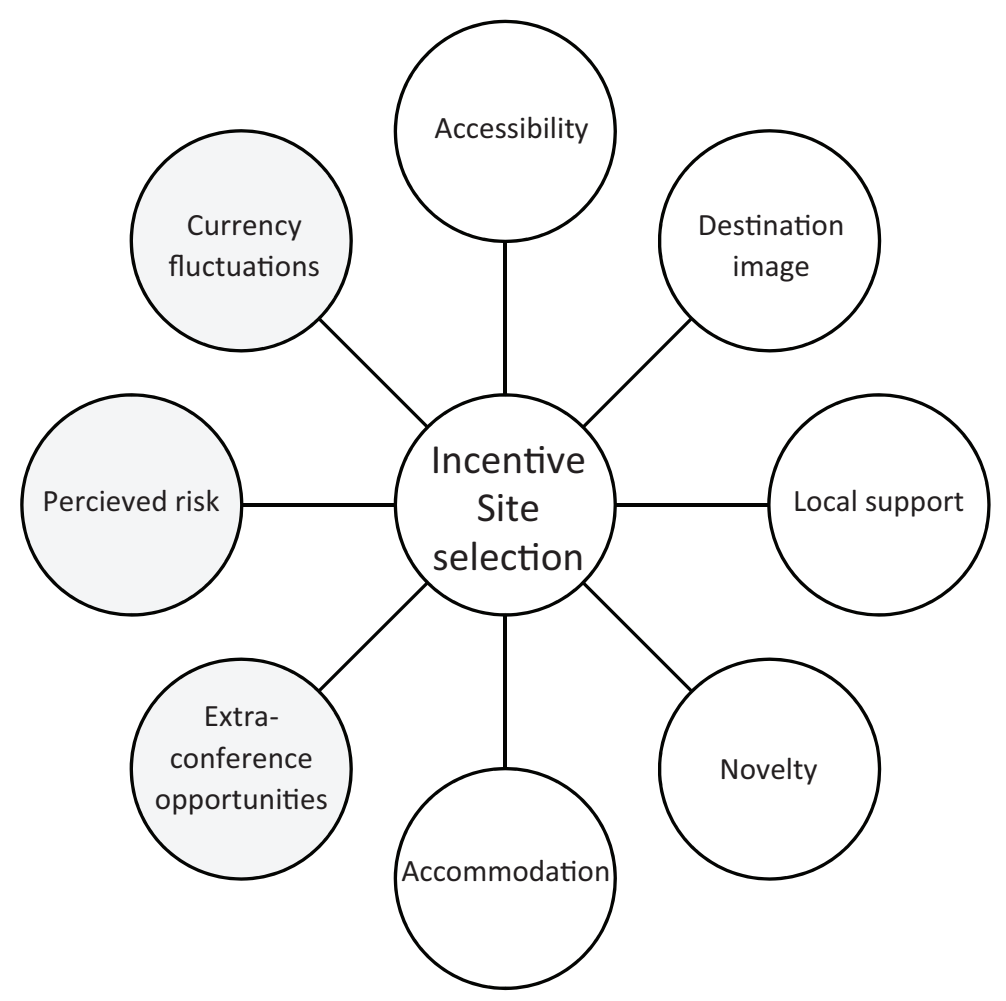

Figure 1. Incentive travel planners' site selection factors.

access, but also that it should have good group travel facilities within the destination as well.

Accommodation. The quality of accommodation was considered to be very important for the American and the Australian planners. One planner noted "if they walk in and they don't see it as being spectacular, they're disappointed." In both countries, the cost of accommodation was something that had to be factored in, although price was not always the deciding factor. Given that incentive trips often involve high-end or luxury components, they are often expensive. However, planners did stress the importance of staying within the client's budget yet offering the best possible products and services within these financial constraints. The Australian planners had a preference for known brands like Hilton or Starwood, and for accommodation that offers extremely high standards of service. However, the Chinese planners, while noting that fouror five-star accommodation was necessary, stated that it was the destination itself that was the draw, and as long as the accommodation was well chosen, this would be sufficient.

Destination Image. Planners identified the importance of selecting a destination that was appealing to those traveling on the incentive trip. This was described as the "wow" factor. The destination should be attractive and appealing, and indeed perhaps aspirational. Other words that were used to describe potential incentive travel destinations included "unique," "luxurious," and "exotic," "memorable," "authentic," and "high profile.” When asked to suggest destinations around the world that were popular for incentive trips, the destinations that were mentioned included Thailand (Bangkok and Phuket); Japan; Singapore; Switzerland; the US (Hawaii, Las Vegas, and New York); Australia (Great Barrier Reef, Sydney, Gold Coast); Italy; France (Paris and the Champagne Houses); South Africa (for safaris); and the Maldives. 
Local Support. Local support, in terms of a destination management company (DMC), or the local convention and visitor bureau (CVB), was seen to be important, but not crucial to organizing an incentive trip. While all planners noted that they did use the services of DMCs from time to time, they felt that a personal site inspection, and finding a DMC that they could trust, were more important than liaising with an unknown company. This links back to the idea of building networks and relationships with suppliers and building trust.

Extra-Conference Opportunities. Only the Chinese planners felt that extra-conference opportunities were an important part of the site selection process. They noted that sightseeing, shopping, relaxing, and enjoyment were all important parts of an incentive trip, and therefore that it was very important that a destination had plenty of opportunities for these activities. For the Australian planners, the key thing was to factor time into the incentive agenda to allow people to spend some time doing their own thing, and relaxing in whatever way they liked (e.g., playing golf, shopping, spa treatments, etc.). The American planners suggested that many incentive travelers spend their free time by the pool, or at the beach, but for incentive travel with significant amounts of leisure time (as opposed to business, education, or team building activities) than the opportunities for shopping and other activities become more important.

Meeting Facilities. The availability of meeting facilities was not seen to be a particularly important issue for the site selection process in the incentive context. Given that most incentive trips are primarily leisure trips, with only a small business component, the interviewees suggested that most hotels could offer business facilities, and that therefore this was not a factor in choosing the destination.

A number of factors that emerged from this research did not appear in the original convention planners' site selection factors literature (e.g., Crouch \& Louviere, 2004). Arguably, some of these factors may fit in the "other" criteria identified previously. Nonetheless, these appear to be factors that are of particular significance to incentive planners.
Novelty. It was suggested by the interviewees that employers offering incentive travel programs usually choose a new place each year. The novelty value of the trip was seen as being an important motivational factor for employees, and something that would encourage them to work to reach their targets. According to one planner, the important thing to think about when planning an incentive is "what's new, what's upcoming, what's exciting, because you really have to have the excitement."

Perceived Risk. There was a range of risks that incentive planners need to take into account when choosing a destination for an incentive trip. These ranged from seasonal (at certain times of the year, some destinations are not suitable for visiting because of the weather) to weather related (e.g., cyclones and hurricanes), to terrorism and political instability. Of course, all meeting planners have to take these into account, but to date the literature has not included these factors as significant when discussing site selection. As well as the risk to those traveling on the incentive trip, there is a risk to the reputation of the incentive planner, and as such, this is an issue that cannot be underestimated.

Currency/Exchange Rates. Fluctuations in exchange rates can be a considerable issue for incentive trips that are planned well in advance. Similar to the issue of perceived risk, this is not solely a problem for the incentive market, but the business events literature has not yet focused on risk to any great extent. Currency fluctuations were perceived by interviewees as being problematic for countries where the exchange rates varied significantly (the US and Europe were specifically mentioned) but this can be to the benefit of other countries where the exchange rates remain more stable (e.g., Switzerland).

\section{Discussion}

This article interviewed incentive operators and examined how incentive travel is conceptualized, planned, and organized in three major marketsAustralia, China, and the US. The finding suggests that planners across the three markets share similar perceptions on what characterizes incentive trips 
(e.g., purpose and components of incentive travel) but differ slightly in the planning and operational phase pertinent to varying customer characteristics and requirements. Despite the ostensible geographical and cultural differences across the three groups, informants share the perception that incentive travel is used as a motivator to enhance corporate performance and employee morale, having a combined business-leisure component, and is affected by a similar set of economic and social factors in the planning and organizing phase.

One notable difference in incentive travel operation among the three markets is the organizational structure of the incentive house. Although the Chinese planners are usually affiliated to a larger tour operation company, the Australian and the American planners are mostly working as a standalone company. However, this difference does not seem to affect the overall operational model of outbound incentive travel, as they all use DMC/ ground operators when planning and conducting incentives overseas. It might be related to the lack of multinational travel corporations that have branches in various locations. Incentive planners thus have to establish quality and binding business relationships with DMCs/ground operators. This is always a challenge, especially to small and medium sized planners, due to possible asymmetric information on local suppliers' capabilities and credit, as well as uncertainties inherently linked with providing products and services with an “above and beyond" expectation.

Another notable difference among the three cohorts lies in the planners' perceived customer demand in luxury level of accommodation, profile of destination, and sophistication of activities. It seems that Australian and American groups emphasize more on incentive trips being "exotic," "aspirational," "luxury," and "high profile.” On the other hand, the Chinese incentive planners and participants pay more attention to the sightseeing and leisure opportunities provided by destinations. Apparently, Chinese incentive participants are more like leisure tourists with a group-tailored travel itinerary—sightseeing, shopping, and some fun group/ team-building activities. DMCs/ground operators should understand the needs and wants of different markets and accordingly vary their product offerings-there is no "one size fits all" approach.
Alternatively, they may choose to become experts in one or more niche areas for specific markets.

This article found that site-specific attributes in site selection for incentive travel are considerably different from those for convention or exhibition site selection, the two other key sectors within MICE (meetings, incentives, conferences, and events). Similar umbrella terms are used in this article (e.g., destination image, local support); however, the relative importance of each sector varies between the MICE sectors. In convention and exhibition site selection, availability of conference/exhibition space is among the most important factors. In the exhibition context, choosing a destination that is seen to be the industry leader in the specific industrial sector of the exhibition is very important (Jin, Weber, \& Bauer, 2012). However, in the incentive travel context, the need to go to a destination with large scale and purpose-built conference and exhibition facilities is reduced to a minimum, as most incentive travel is conducted in small groups. Likewise, the accommodation factor becomes less important as choices for accommodation range and rate are abundant in most established destinations. The most similar factor between site selection for convention and incentive travel might be accessibility - travel distance, costs, convenience of travel connection. In this regard, convention planners may choose a destination that offers an opportunity to attract new association members. Alternatively, convention planners may place more emphasis on the proximity of a convention destination to the majority of the association members, in order to keep costs down for attendees. However, incentive planners do not need to worry about the costs to individual attendees, as the costs are borne by the organization arranging the trip. In the incentive travel context, according to the informants of this study, destination factors (e.g., high profile image, touristic value, physical setting, opportunities for entertainment and recreation, shopping, safety and security) seem to be the most important factor. This suggests that future studies can utilize destination factors important to leisure/ group-leisure tourists to explore factors important for incentive travel site selection.

Finally, incentive travel appears to be affected by economic, social, and ideological factors. However, the impact of these factors varies from market to market. For example, Australia and the US incentive planners seem to be influenced by the 
prevailing economic conditions, the perceived value of incentive travel as a motivator for corporate productivity, and ethical considerations. The Chinese market, on the other hand, is more vulnerable to political changes in corporate policies (e.g., government tightening public/corporate spending).

\section{Conclusion}

This article explored site selection of incentive travel from the perspective of incentive operators/ planners. However, as indicated by informants, decision making is largely a collective activity by participating persons from two parties-the corporate and the incentive house/company. In most cases, the decision making consists of a group of people. Further research should explore the conceptualization of incentive travel, knowledge, strategic management, and site selection factors from the corporate perspective, as corporate characteristics such as size and industry type might influence decision making related to incentive travel. Studies could also examine the power of planners in decision making as against that of the corporate decision makers. Such studies would help DMOs trying to encourage incentive groups to visit their locality.

A limitation of this research that should be acknowledged is the small sample size. As such, the findings are preliminary in nature, and should not be taken as representative of the whole incentive sector. However, the initial conclusions from this research suggest that, while the site selection factors identified in the convention planning literature provide a useful place to start, incentive travel organizers do not rely solely on these factors. In particular, the ideas of aspirational destinations, and providing a unique, novel, and exciting experience lend themselves to further research. The findings from this project will provide a basis for future research in the area of incentive, and useful information for incentive planners/organizers in Australia and worldwide.

\section{References}

Bonn, M. A., Brand, R. R., \& Ohlin, J. B. (1994). Site selection for professional meetings: A comparison of heavy half v. light half association and corporation meeting planners. Journal of Travel and Tourism Marketing, 3(2), 59-84.
Buchanan, D., \& Bryman, A. (2009). The SAGE handbook of organisational research methods. Thousand Oaks, CA: Sage Publishing.

Chacko, H. E., \& Fenich, G. G. (2000) Determining the importance of US convention destination attributes. Journal of Vacation Marketing, 6(3), 211-220.

Chen, C. F. (2006) Applying the analytical hierarchy process (AHP) approach to convention site selection. Journal of Travel Research, 45(2), 167-174.

Clark, J. D., Evans, M. R., \& Knutson, B. J. (1998). Selecting a site for an association convention. Journal of Hospitality \& Leisure Marketing, 5(1), 81-93.

Comas, M., \& Moscardo, G. (2005) Understanding associations and their conference decision-making processes. Journal of Convention \& Event Tourism, 7(3/4), 117-138.

Crouch, G. (2011). Destination competitiveness: An analysis of determinant attributes. Journal of Travel Research, 50(1), 27-45.

Crouch, G., \& Louviere, J. (2004). The determinants of convention site selection: A logistic choice model from experimental data. Journal of Travel Research, 43(2), 118-130.

Crouch, G., \& Ritchie, B. (1997) Convention site selection research: A review, conceptual model, and propositional framework. Journal of Convention \& Exhibition Management, 1(1), 49-69.

Deery, M., Jago, L., Fredline, L., \& Dwyer, L. (2005). National business events study. Altona, Australia: Common Ground.

Del Chiappa, G. (2012). How do meeting organizers choose convention sites based on different types of Meetings? An empirical analysis of the Italian meetings industry. Event Management, 16(2), 157-170.

Di Pietro, R. B., Breiter, D., Rompf, P., \& Godlewska, M. (2008). An exploratory study of differences among meeting and exhibition planners in their destination selection criteria. Journal of Convention \& Event Tourism, 9(4), 258-276.

Draper, J., Dawson, M., \& Casey, E. (2011). An exploratory study of the importance of sustainable practices in the meeting and convention site selection process. Journal of Convention \& Event Tourism, 12(3), 153-178.

Fortin, P. A., \& Ritchie, J. R. B. (1977). An empirical study of association decision processes in convention site selection. Journal of Travel Research, 15(4), 13-20.

Go, F., \& Zhang, W. (1997). Applying importance-performance analysis to Beijing as an international meeting destination. Journal of Travel Research, 35(4), 42-49.

Grant, Y. N. (1994). Factors that contribute to the selection process of meetings from the perspective of the attendee. Proceedings of the Annual CHRIE Conference, July 27-30, Palm Springs, CA.

Hall, T., \& Ledger, A. (2013). UK events industry worth \$60bn, reveals MPI study. Conference and Incentive Travel Magazine. Retrieved from http://www.citmagazine.com/article/1190234/uk-events-industry-worth60bn-reveals-mpi-study 
Hilliard, T. W., \& Baloglu, S. (2008). Safety and security as part of the hotel servicescape for meeting planners. Journal of Convention \& Event Tourism, 9(1), 15-34.

Incentive Travel and Corporate Meetings. (2015). Melbourne attracts Indonesia's largest incentive group. Retrieved from http://www.incentivetravel.co.uk/news/ australia/24693-melbourne-attracts-australia-s-largestindonesian-incentive-group

Jago, L., Mair, J., Deery, M., \& Bergin-Seers, S. (2008). A review of the business events sector 2003-2008. Melbourne, Australia: Centre for Tourism and Services Research Victoria University.

Jin, X., Weber, K., \& Bauer, T. (2012). Impact of clusters on exhibition destination attractiveness: Evidence from Mainland China. Tourism Management, 33(6), 1429-1439.

Jun, J., \& McCleary, K. W. (1999). Classifying US association meeting planners based on international destination selection criteria: A case study of South Korea. International Journal of Hospitality Management, 18, 183-199.

Lee, M. J., \& Back, K.-J. (2005). A review of convention and meeting management research 1990-2003: Identification of statistical methods and subject areas. Journal of Convention \& Event Tourism, 7(2), 1-20.

Lee, M. J., \& Back, K.-J. (2007). Effects of destination image on meeting participation intentions: Empirical findings from a professional association and its annual convention. The Service Industries Journal, 27(1), 59-73.

Lee, S., Park, K., \& Khan, M. (2012). Perceived importance of ICT-based features and services on convention center site selection differences among meeting planners. Journal of Hospitality and Tourism Technology, 3(1), 32-46.

Mair, J. (2005). Towards a model of the UK association conference attendance decision making process. Unpublished Ph.D. thesis, Scottish Hotel School, University of Strathclyde, Glasgow.

Mair, J. (2012). A review of business events literature. Event Management, 16(2), 133-141.
Mair, J. (2014). Conferences and conventions: A research perspective. Abingdon, Oxon: Routledge.

Melbourne Convention and Visitor Bureau. (2010). Melbourne convention and visitor bureau annual report. Melbourne, Australia: Author.

Montgomery, R. J., \& Strick, S. K. (1995). Meetings, conventions and expositions - an introduction to the industry. New York: Van Nostrand Reinhold.

Oppermann, M. (1995). Professional conference attendees' and non-attendees' participation decision factors. In Proceedings of the Society of Travel and Tourism Educators Annual Conference, Denver, CO.

Oppermann, M. (1996). Convention cities-images and changing fortunes. The Journal of Tourism Studies, 7(1), 10-19.

Sanders, K. (2011). The true value of the United States meeting and events industry. Retrieved from http:// planyourmeetings.com/2011/03/25/the-true-value-ofthe-u-s-meetings-and-events-industry/

Sheldon, P. J. (1995). The demand for incentive travel: An empirical study. Journal of Travel Research, 33(4), 23-28.

Shinew, K. J., \& Backman, S. J. (1995). Incentive travel: An attractive option. Tourism Management, 16(4), 285-293.

Society of Incentive Travel Executives. (2013). About SITE. Retrieved from http://www.siteglobal.com/p/cm/ld/fid=18

Strauss, A., \& Corbin, J. (1990). Basics of qualitative research: Grounded theory procedures and techniques. Newbury Park, CA: Sage.

Tourism Australia. (2008). Preliminary business events report (March Quarter). Sydney, Australia: Author.

Xiang, Z., \& Formica, S. (2007). Mapping environmental change in tourism: A study of the incentive travel industry. Tourism Management, 28(5), 1193-1202.

Yoo, J., \& Chon, K. (2008). Factors affecting convention participation decision-making: Developing a measurement scale. Journal of Travel Research, 47(1), 113-122.

Yoo, J., \& Zhao, X. (2010). Revisiting determinants of convention participation decision-making. Journal of Travel \& Tourism Marketing, 27(2), 179-192. 